\title{
経皮的超音波腎砕石術に使用する灌流液の血清電解質・ 浸透圧に及ぼす影響
}

\begin{tabular}{|c|c|c|c|c|}
\hline & 馬 & 昜 & 志 & 郎 \\
\hline & 丸 & 茂 & & 健 ${ }^{*}$ \\
\hline & 長 & 谷 川 & 親 太 & 郎 \\
\hline & 田 & 野 口 & & 仁 \\
\hline & 塚 & 本 & 拓 & 司 \\
\hline & 大 & 橋 & 正 & 和 \\
\hline & 中 & 島 & 洋 & 介 \\
\hline \multirow{6}{*}{ 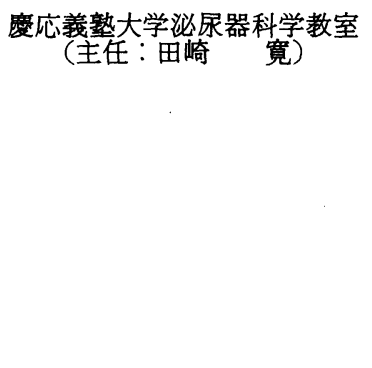 } & 中 & 村 & & \\
\hline & 中 & 薗 & 昌 & 明 \\
\hline & 出 & 口 & 修 & 宏 \\
\hline & 村 & 井 & & 勝 \\
\hline & 実 & 川 & 正 & 道 \\
\hline & 田 & & & 寛 \\
\hline
\end{tabular}

\section{FLUID ABSORPTION DURING PERCUTANEOUS ULTRASONIC NEPHROLITHOTRIPSY}

Shiro Baba, Ken Marumo*, Shintaro Hasegawa, Hitoshi Tanoguchi, Takuji Tsukamoto, Masakazu Ohashi, Yosuke Nakajima, Kaoru Nakamura, Masaaki Nakazono, Nobuhiro Deguchi, Masaru Murai, Seido Jitsukawa and Hiroshi Tazaki

Department of Urology, School of Medicine, Keio University *Department of Urology, Tokyo Electric Power Hospital

The present study was performed to examine whether irrigant solution is absorbed to the systemic circulation by percutaneous ultrasonic nephrolithotripsy (PUN) enough to cause any significant changes of serum electrolytes or hematocrit level. Using $2.7 \% \mathrm{D}$-sorbitol-0.54\% D-mannitol or 3\% D-sorbitol solution as irrigant, serum electrolytes, osmolarity and hematocrit were measured before and immediately after PUN in 10 patients with renal stones. The osmolarity gap, which is the difference between the measured osmolarity after PUN and that calculated from the formula $\left\{2 \mathrm{Na}+\frac{1}{3} \mathrm{BUN}+\frac{1}{18}\right.$ glucose\}, was thought to be a useful indicator to estimate the amount of irrigant fluid absorption. The irrigant bag was placed $100 \mathrm{~cm}$ above the level of the kidney, while the fluid in the renal pelvis was constantly aspirated by the equipped peristaltic pump. The intrapelvic pressure, thus, was maintained between 40 and $60 \mathrm{cmH}_{2} \mathrm{O}$.

After PUN, there was a slight, insignificant decrease in serum sodium concentration. The hematocrit level, however, decreased significantly $(p<0.05)$ and this decrease correlated well with the amount of irrigant fluid used in PUN. The measured osmolarity gap after PUN averaged $10.4 \pm$ $7.4 \mathrm{mOsm} / \mathrm{L}$ (mean \pm S.D.). The amount of irrigant absorption, which was estimated from the osmolarity gap, ranged from 300 to $800 \mathrm{ml}$ under the particular irrigation method mentioned above. There was, however, no single patient who complained of any clinical symptoms caused by water intoxication, and the postoperative convalescence was uneventful in all the patients.

*現 東京電力病院泌尿器科 
From these observations, it is concluded that PUN is a safe procedure and the amount of fluid absorption during this procedure is within acceptable range, if the intrapelvic pressure is kept below $60 \mathrm{cmH}_{2} \mathrm{O}$.

\begin{abstract}
要旨：経皮的超音波腎砕石術に使用する灌流液と灌流条件の血清浸透圧，電解質, Ht に及ぼす影響を検 討する目的で10症例の腎結石患者で手術前後の測定値を検討した．灌流液はD-マニトール・ソルビトー ル混合液かもしくは $3 \% \mathrm{D}$-ソルビトール液を用い, $100 \mathrm{cmH}_{2} \mathrm{O}$ 圧下で低圧持続吸引灌流を行った。 この時 の腎孟内圧は $40 \sim 60 \mathrm{cmH}_{2} \mathrm{O}$ に相当した。術後血清ナトリウム值はやや減少するも有意差はなく, Ht 值 は術前に比較し有意に減少した $(\mathrm{p}<0.05)$.

手術前後の血清浸透圧実測値には著明な变動はなかった。術後の浸透圧理論値を血糖値, $\mathrm{Na}, \mathrm{BUN}$ 濃 度より計算し, 術後の浸透圧実測值との差（osmolarity gap）を灌流液体内吸収の指標とした。その平 均値は10.4 7 7.4mOsm/L (mean \pm S.D.) であり，術中に $300 \sim 800 \mathrm{ml}$ の灌流液が腎盂より吸収されるも のと推定された. 術後の臨床症状から disequilibration syndromeをきたした症例はなかった。 以上の事 実から本法に使用する灌流液は末梢循環血液中に吸収されるものの, 腎孟内圧を $60 \mathrm{cmH}_{2} \mathrm{O}$ 以下に保持 すればその吸収量は少いことが判明した。
\end{abstract}

\section{緒 言}

腎結石に対して経皮的手術操作を試みた歴史は古 く，すでに10世紀後半に経皮的腎切石術（percutaneous nephrolithotomy）が行われた記録がある. 1955年に Goodwin ら ${ }^{11}$ にり経皮的腎孟穿刺, 腎瘻造 設術の安全性が報告され，さらには碎石用超音波プ ローベが開発されて以来, 経皮的超音波腎砕石術(percutaneous ultrasonic nephrolithotripsy : PUN) が急 速に普及し1980年代のはじまりとともに多数例に施行 されるようになってきた2). しかし腎結石に対する経 皮的手術法の安全性に関しては未だ議論の余地のある ところで, とくにネフロスコープ (nephroscope) 操作 時の腎盂灌流条件々灌流液の体内吸収量に関しては報 告がきわめて少い(3)。そこで著者らは慶応義塾大学病 院怙よび東京電力病院で, 一定の灌流条件下で経皮的 超音波腎砕石術（以後 PUN）を施行した症例の術前術 後の血清電解質, 浸透圧, 腎機能を検討し, 安全な灌 流圧を設定し得たので以下に報告する。

\section{対象および方法}

対象は10例の腎孟または腎杯結石患者で，年齢は20 歳から64歳まで (平均39.2歳) 性別は男性 9 例, 女性 1 例であった(表 1 ). 結石の大きさは腹部単純 $\mathrm{X}$ 線撮 影上, 最大 $2.6 \times 1.6 \mathrm{~cm}$ で珊瑚状結石は含まれていな い. 患側は左側 6 例, 右側 4 例で主要な結石の位置は 腎孟内が 5 例, 腎孟尿管移行部 (以下 PUJ) 4 例, 下 腎杯が 1 例であった。腎孟内結石症例のうち 3 例には 下腎杯にも小結石が合併し, 超音波碎石術により除去 した. 今回の研究対象となった 10 症例のうち, 過去に
表 1 経皮的超音波腎砕石術症例

\begin{tabular}{|c|c|c|c|c|c|c|c|}
\hline & 年数 & 性別 & 結石部位 & $\begin{array}{c}\text { 大きさ } \\
(\mathrm{cm})\end{array}$ & 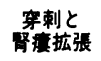 & $\underset{(\min )}{\text { 手術時間 }}$ & $\begin{array}{c}\text { 使用灌流液 } \\
(\mathrm{L})\end{array}$ \\
\hline 1.K.W. & 51 & 男 & 左瞥孟 & $1.5 \times 1.0$ & 2 期 & 70 & $0.5^{*}$ \\
\hline 2.T.U. & 32 & 男 & 右下督杯 & $2.6 \times 1.2$ & 2 期 & 97 & $10.0^{* *}$ \\
\hline 3. K.T. & 30 & 男 & 左PUJ & $1.4 \times 1.5$ & 2 期 & 90 & $8.0^{* *}$ \\
\hline 4.H.S. & 25 & 女 & 左PUJ. & $1.2 \times 0.6$ & 1 期 & 70 & $0.6^{*}$ \\
\hline 5.K.K. & 20 & 男 & 右PUJ & $2.0 \times 1.2$ & 1 期 & 50 & $6.0^{* *}$ \\
\hline 6.S.H. & 39 & 男 & 左督 血 & $1.2 \times 1.3$ & 1 期 & 35 & $2.0^{* *}$ \\
\hline 7.K.Y. & 37 & 男 & 右PUJ & $1.4 \times 1.5$ & 1 期 & 60 & $5.7^{* *}$ \\
\hline 8. T.M. & 53 & 男 & 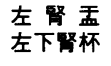 & $\begin{array}{l}2.1 \times 1.3 \\
1.2 \times 0.6\end{array}$ & 1 期 & 50 & $3.5^{* *}$ \\
\hline 9. K.O. & 64 & 男 & $\begin{array}{l}\text { 左督盖 } \\
\text { 左下筩杯 }\end{array}$ & $\begin{array}{l}2.4 \times 1.8 \\
1.0 \times 0.7\end{array}$ & 1 期 & 62 & $4.5^{* *}$ \\
\hline 10. S.K. & 35 & 男 & 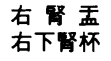 & $\begin{array}{l}2.6 \times 1.6 \\
0.3 \times 0.3\end{array}$ & 1 期 & 105 & $3.4^{* *}$ \\
\hline
\end{tabular}

*2.7\%D-ソルヒトール・0.54\%D-マニトール混合液 $* * 3 \%$ D・ソルヒトール

表 2 経皮的超音波腎碎石術前後の臨床検査值の変化 (mean \pm S.D.)

\begin{tabular}{|c|c|c|}
\hline & 術 前 & 術 \\
\hline 血清 漫透压 (mOsm/L) & $303.2 \pm 10.8$ & $299.2 \pm 4.9$ \\
\hline ヘマトクリット (\%) & $44.2 \pm 4.7$ & $38.5 \pm 5.8^{*}$ \\
\hline 血清ナトリウム (mEq/L) & $143.5 \pm 2.3$ & $140.1 \pm 4.0$ \\
\hline 血清クレアチニン(mg/dl) & $1.02 \pm 0.18$ & $1.12 \pm 0.32$ \\
\hline クレアチニンクリアランス $(\mathrm{ml} / \mathrm{min})$ & $113.4 \pm 60.2$ & $121.9 \pm 25.7$ \\
\hline
\end{tabular}

腎孟切石術を受けた症例は 2 例(表 $2:$ 症例 No. 1,9) であった。

このらち 1 症例(症例 No. 9)は以前に他施設で施行 
図 1 経皮的超音波腎碎石術に抢ける腎孟灌流システムと内圧測定法

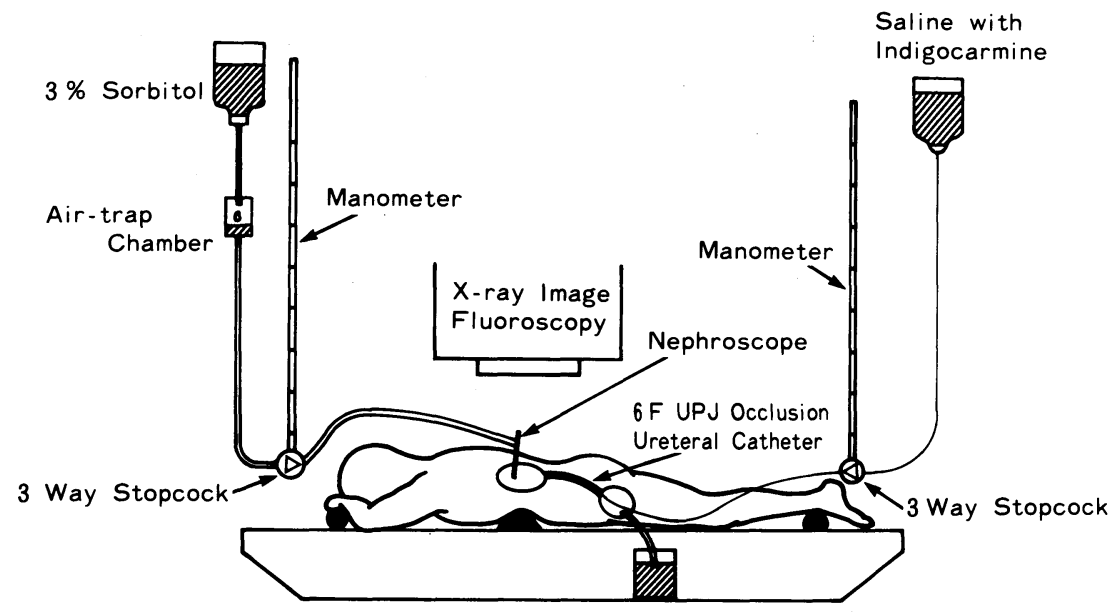

された腎昷切石術と同側に結石が再発し PUN の対象 となった。術前検查として全例に血清 $\mathrm{Ca}, \mathrm{P}, \% \mathrm{TRP}$ (tubular reabsorption of phosphate), 尿中 $\mathrm{Ca}$ 排出量 を測定した.

術前の処置として手術当日, 腹部単純 $\mathrm{X}$ 線撮影のの ち逆行性に $6 \mathrm{~F}$ occlusion balloon catheter (Cook Urological, U.S.A.) 患側尿管に留置し逆行性腎孟造 影を施行したのち, $0.5 \sim 1 \mathrm{ml}$ の生理食塩水でバルーン を満し, カテーテル先端が腎孟尿管移行部となるよう 固定した。この操作は後述する経皮的腎监穿刺を容易 にし，また超音波碎石術中に結石小片が尿管内に流入 することを未然に防止しうるため非常に重要である. 尿管カテーテルを留置したのち, 膀脱内に $18 \mathrm{~F}$ Foley バルーンカテーテルを留置固定する，経皮的腎盐穿刺 は上記操作に引き続き, 腰麻下もしくは全麻下で患者 を腹臥位とし超音波監視下で18G Chiba needleを用 いて行った.

穿刺直前に尿管カテーテルより腎孟内にインジゴカ ルミンを含む生理食塩水を約 $10 \mathrm{ml}$ 緩徐に注入してお き，腎孟穿刺時に容易に確認し得るようにした。穿刺 は全例腎下極後面で下腎杯に刺入するように努めた。 腎孟穿刺直後に経皮的腎孟造影を行い, X線透視下に ガイドワイヤーを腎孟内に㨂入し Chiba needleを抜 去した。はじめの 3 症例は腎孟穿刺後 $9 \mathrm{~F}$ の selfretaining catheterを留置し 2 日ないし 3 日後に腎瘦 を払張した. しかしその後の 7 症例には腎孟穿刺後 1 期的に腎瘦を telescope-bougie (Karl-Stolz)にて拡張 し $26 \mathrm{~F}$ 手術用外套管を插入した。使用した灌流液は $2.7 \% \mathrm{D}$-ソルビトール・0.54\%D-マニトール混合液（ウ
リガール)、または $3 \% \mathrm{D}$ ・ソル゙トール液のどちらか を選んだ。灌流時は液面と腎との距離を $100 \mathrm{~cm}$ とし た。術中の腎盂内圧は尿管 balloon catheter の途中の 回路を用いて測定した（図 1)。また灌流液の流入側で も同時に水柱圧を記録した。手術用内視鏡を外套管に 装着したのち，まず腎孟内を観察し結石の確認のほか 腎孟粘膜の異常の有無につき検討したのち超音波プ

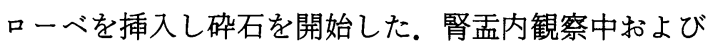
碚石術中は常に灌流液を持続低圧吸引して腎孟内圧を 一定に保つょうにした。砕石終了後, 透視下で残石の 有無を検討した。 $13 \mathrm{E}$ ネラトンカテーテルを手術用外 套管内腔より腎孟内に指入し，外套管を抜去，ネトラ ンカテーテルを皮膚に縫合固定したのち造影剂を注入 して腎瘦造影を行い造影剂溢流の有無を観察した。

手術前と手術直後に末梢血, 血清浸透圧 (氷点降下 法：Osmette 2007型)，血清電解質, BUN, 血糖値を測 定した。また腎機能の指標として血清クレアチニン值 を測定したほか, 手術前後の内因性クレアチニンクリ アランス（以下 GFR）を比較した. 術後 3 日〜 4 日目 にネラトンカテーテルを抜去しその先端を一般細菌培 養検査に供した。腎孟灌流液の吸収量を推定する目的 で手術直後の血清 $\mathrm{Na}, \mathrm{BUN}$, 血糖値から血清浸透圧 理論值 $\llbracket 2 \times \mathrm{Na}(\mathrm{mEq} / \mathrm{L})+\frac{1}{3} \mathrm{BUN}(\mathrm{mg} / \mathrm{dl})+\frac{1}{18}$ glucose $(\mathrm{mg} / \mathrm{dl})$ ]を計算し，各症例ごとに血清浸透圧 実測値から理論計算值を差し引き osmolarity gap 計測した。

\section{結 果}

結石破砕吸引に要した手術時間は35分から105分 


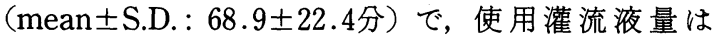

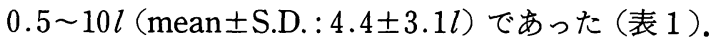
灌流液面を腎孟より $100 \mathrm{~cm}$ とし，超音波プローべ内腔 より持続吸引した場合の腎孟内圧は $40 \sim 60 \mathrm{cmH}_{2} \mathrm{O}$ で あった。この值は, 灌液液の内視鏡流入口内圧とほ匡 一致した。

術前の血清 $\mathrm{Ca}, \mathrm{P}$ ，尿中 $\mathrm{Ca}$ 排泄量ならびに\% $\mathrm{TRP}$ 值は10症例とも正常範囲内であった. PUN 終了時の 腎瘻造影では 3 症例に腎穿刺部から腎周囲への造影剂 の溢流がみられたが，腎静脈への溢流所見を呈した症 例はなかった.PUN 前後の臨床検査測定値を表 2 に 示した。術前の血清浸透圧は303.2 $\pm 10.8 \mathrm{mOsm} / \mathrm{L}$ (mean \pm S.D.) で術直後の $299.2 \pm 4.9 \mathrm{mOsm} / \mathrm{L}$ と比較 し有意差はみられなかった。へマトクリット $(\mathrm{Ht})$ 值 は術前の $44.2 \pm 4.7 \%$ (mean \pm S.D.) から術後 $38.5 \pm$ $5.8 \%$ (mean \pm S.D.) へと有意に低下した $(\mathrm{p}<0.05)$. 血清 $\mathrm{Na}$ 值も術前の $143.5 \pm 2.3 \mathrm{mEq} / \mathrm{L}$ (mean \pm S.D.)

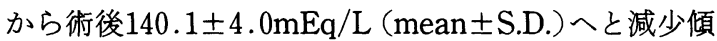
向がみられたが統計学的な有意差はみられなかった。 PUN 術中ならびに術後 7 日間の血圧の変動も著明な ものはなかった。血清クレアチニン值は術前の $1.02 \pm$ $0.18 \mathrm{mg} / \mathrm{dl}$ （mean \pm S.D), 術 後 $1.12 \pm 0.32 \mathrm{mg} / \mathrm{dl}$ (mean \pm S.D.) でやや PUN 直後に一過性に上昇した が統計学的有意差はなく, 退院時に測定した G.F.R.は $121.9 \pm 25.7 \mathrm{ml} / \mathrm{min}$ と術前の $113.4 \pm 60.2 \mathrm{ml} / \mathrm{min}$ (mean \pm S.D.) に比較し軽度の増加がみられた. PUN 術後の患者の疼痛は軽微で術後 2 日ないし 3 日で離床 が可能であった. また10症例のらちで 1 例も術後 disequilibration syndromeを示唆するような臨床症状は みられなかった. PUN 前後でみられた $\mathrm{Ht}$ 值および血 清 $\mathrm{Na}$ 濃度の変動率を術前の測定值に対する百分率で 示すと, 10 症例の $\mathrm{Ht}$ 值の変動率 $(\Delta \mathrm{Ht})$ は12.3土 $11.4 \%$ (mean \pm S.D.) であった. 次に個々の症例の手 術時間と $\Delta \mathrm{Ht}$ もしくは $\Delta \mathrm{Na}$ との相関関係を検討し たが相関係数はきわめて低かった $(\mathrm{r}=0.33,0.07)$. し かし使用灌流液量 $(\mathrm{x})$ と $\mathrm{Ht}(\mathrm{y})$ との間の相関は $\mathrm{y}=$ $2.24 \mathrm{x}+2.37(\mathrm{r}=0.61)$ で表わされ, 比較的高い相関 を示した。

手術直後の血清浸透圧実測値と血清 $\mathrm{Na}, \mathrm{BUN}$ おう び血糖値から算出された浸透圧理論値との差は10症例 で0.4から $26.3 \mathrm{mOsm} / \mathrm{L}$ で平均 $10.4 \pm 7.4 \mathrm{mOsm} / \mathrm{L}$ （mean \pm S.D.）であった（表 3 ），血糖值はglucose oxidase 酵素電極法で測定され，sorbitol による干渉 を無視し得るものと考劣れば,この osmolarity gap は
表 3 術後血清浸透圧の実測値と理論値との差（Osmolarity Gap)

\begin{tabular}{|c|c|c|c|}
\hline & \multicolumn{2}{|c|}{ 血清漫透圧理論值 $=2 \times \mathrm{Na} \mathrm{mEq} / \mathrm{L}+\frac{\mathrm{BUN}}{3}$} & $+\frac{\text { Glucose }}{18}$ \\
\hline & (A) 実測値 (mOsm/L) & (B) 理論値 (mOsm/L) & $\begin{array}{c}\text { Osmolarity Gap } \\
\text { (A) - (B) }\end{array}$ \\
\hline I.K.W. & 294.0 & 293.6 & 0.4 \\
\hline 2.T.U. & 301.0 & 282.1 & 18.9 \\
\hline 3.K. T. & 298.0 & 289.0 & 7.0 \\
\hline 4. H.S. & 298.0 & 288.9 & 9.1 \\
\hline $5 . \mathrm{K} . \mathrm{K}$. & 302.0 & 291.3 & 10.7 \\
\hline 6. S. H. & 302.5 & 290.5 & 12.0 \\
\hline $7 . \mathrm{K} . \mathrm{Y}$. & 325.0 & 298.7 & 26.3 \\
\hline 8.T.M. & 303.8 & 294.3 & 9.5 \\
\hline $9 . \mathrm{K} . \mathrm{O}$. & 300.0 & 294.9 & 5.1 \\
\hline 10. S.K. & 289.2 & 284.0 & 5.2 \\
\hline
\end{tabular}

腎孟内灌流液が循環血液内に吸収された量に比例して 増加する。

今回の臨床研究では腎孟内圧は $40 \sim 60 \mathrm{cmH}_{2} \mathrm{O}$ に保 持されており, osmolarity gap は使用された灌流液量 との間に正の相関を示した $(\mathrm{y}=1.19 \mathrm{x}+5.16: \mathrm{y}:$ osmolarity gap, $\mathrm{x}$ : 灌流液量, $\mathrm{r}=0.49)$. しかし観察さ れた osmolarity gap はいずれも $30 \mathrm{mOsm} / \mathrm{L}$ 以下で, 穿刺と腎瘦执張，砕石術を一時期に行った 7 症例でも disequilibration syndromeを括こしらるような高い osmolarity gap $(40 \mathrm{mOsm} / \mathrm{L} \text { 以上 })^{4)}$ を認めた症例は なかった。

PUN による10症例の治療成績は残石症例が 1 例で 治癒率は90\%であった。この症例（表 1 ：症例 No. 2) は腹側下腎杯に嵌頓した結石を有し，その解剖学的位 置関係から超音波碎石用プローベの到達がきわめて困 難であり，PUN 術後残石が尿管に嵌頓したため尿管 切石術を施行して軽快せしめた。

経皮的超音波腎砕石術 (PUN) に腎孟灌流を必要と する理由は，術中に腎盂内の明瞭な視野を確保するこ とと超音波プローべが発生する熱を冷却し腎孟粘膜を 保護することにある5).

この目的で使用されている灌流液には生理食塩水, グリシンあるいはソルビトール，ソルビトール・マニ トール混合液などがあるが，術中電気凝固・切開の併 用を考慮し，欧米の多くの施設は後者の等張糖液を用 いていることが多い，著者らも PUN を腎結石治療へ 導入するにあたり，同様の理由で灌流液に等張糖液を 用いることとした。従来腎孟灌流液の体内吸収に関す る所見は，主に尿管カテーテルによる腎孟洗浄を腎結 
石溶解の目的で施行した臨床症例や動物実験から得ら れているにすぎない. Mulvaney, W.P.6)は犬を用いた 動物実験から正常腎では腎孟内圧を $18 \mathrm{cmHg}$.（230 $\mathrm{cmH}_{2} \mathrm{O}$ ) 以上にすると腎孟灌流液の吸収が増加すると 報告している。一方 Köhler.R. $\left.{ }^{7}\right)^{4}$ 逆行性腎孟造影所見 から造影剤の腎孟・腎杯外への溢流は腎孟内圧がわず か80 100 $\mathrm{mmHg}\left(10 \sim 13 \mathrm{cmH}_{2} \mathrm{O}\right)$ 以上で高頻度に認 められるようになると報告している。

腎孟灌流液の吸収経路は, pyelotubular backflow, pyelovenous backflow, pyelosinus backflow ぞが 考えられているが，堅実質を穿刺するPUN に際して は灌流液の体内吸収の可能性はさらに高いと考兄られ る.しかし PUN に用いる腎孟灌流液は患側尿管を通 じて膀脱へも入り対側腎からの尿と混ざるため正確な 回収量の測定は困難である。ささら血中に吸収された ソルビトールはすみやかに代謝されるため吸収量の測 定も困難である。そこで, PUN 前後の $\mathrm{Ht}$ 值, $\mathrm{Na}$ 濃 度の变化を検討し,さらに osmolarity gap を灌流液吸 収量の指標とした。

著者らはPUN 術中の腎孟内圧を一定のレベルに保 持するため，灌流液水面を腎衁より $100 \mathrm{~cm}$ 上部に設定 した。ささらに灌流速度は吸引用の peristaltic pump を 調整することにより良好な視界を得る最低速度とし た。症例により穿刺部より出血がみられる場合には灌 流速度を増やし，従って使用灌流液量もこのような症 例は多くなる傾向にあった，以上の条件下で腎孟内圧 を occlusion balloon catheterを使用して測定する と, 灌流中腎孟内压は $40 \sim 60 \mathrm{cmH}_{2} \mathrm{O}$ の範囲にあり, 同 時に測定した灌流液流入口内压と注汸一致した. PUN による灌流液の吸収量は，腎孟内压のほかに灌流手術 時間，灌流液使用量，腎実質穿刺部位ならびに穿刺と 腎瘦拡張の時期によって影響を受けると考えられた。

そこでまず PUN 術前扣よび術直後の臨床検查值か ら最も変化のあった $\mathrm{Ht}$ 値および血清 $\mathrm{Na}$ 濃度と上述 の因子との相関について検討した。

その結果手術時間の長さと関係なく $\mathrm{Ht}$ 值は術後有 意に減少しその減少率 $(\Delta \mathrm{Ht})$ は使用灌流液量と比較的 高い正の相関のあることが示された。ささらに灌流液の 体内吸収量を推定するために osmolarity gap を個々 の症例について検討した結果, osmorality gap は使用 灌流液量に比例して増加する傾向がみられた。これら の事実により，腎孟穿刺による腎孟灌流は40～60 $\mathrm{cmH}_{2} \mathrm{O}$ 程度の圧力下でも灌流液の循環血液中の吸収
は皆無ではなく，3\%D-ソルビトール灌流液（165 $\mathrm{mOsm} / \mathrm{L}$ ) で換算した場合，300～800 $\mathrm{ml}$ の灌流液が吸 収されたことになる。この吸収量は穿刺と払張を 2 期 に分けて行っても 1 期的に行っても大差はなくいずれ も吸収量は軽微で，また臨床的にも disequilibration syndromeをきたした症例はなかった，従って腎内視 鏡操作時に灌流と同時の低圧持続吸引を行い腎盂内圧 を $60 \mathrm{cmH}_{2} \mathrm{O}$ 以下に保持すれば， 2 時間以内の PUN はきわめて安全な術式であると考兄られた。しかし， 結石症例の多くは腎血腎炎や膿腎症を合併して拈り， 灌流液の吸収量が前述条件下では軽微であるとい兄ど も尿路感染症合併例では菌血症の危険は非常に高いと 考えられる。

このような感染合併症例には腎孟穿刺前に充分な化 学療法を施行することはきわめて大切で，症例によっ ては腎瘻を設置して腎監堅の推移を観察し，PUN の実施時期を慎重に選択すべきである。

\section{結 語}

PUN 施行時の腎孟灌流液の体内吸収量を一定の灌 流条件下で10症例について検討した。 その結果腎孟内 圧を低圧持続吸引により $60 \mathrm{cmH}_{2} \mathrm{O}$ 以下に設定すれ ば，2 時間以内の PUN 術中に吸収される灌流液量は 計算された osmolarity gap か $5800 \mathrm{ml}$ 以下と推定さ れた。感染合併症例には菌血症の危険は高く PUN 施 行時期を慎重に決定すべき点を強調した。

\section{References}

1) Goodwin, W.E., Casey, W.C. and Wolf, W.: Percutaneous trocar nephrostomy in hydronephrosis. J. Am. Med. Assc., 159, 891-893, 1955.

2) Alken, P., Hutschenreiter, G, Gunther, R., and Marberger, M. : Percutaneous stone manipulation. J. Urol., 125, 463-466, 1981.

3) Wickham, J.E.A. and Miller, R.A.: Percutaneuous Renal Surgery. p. 119, Churchill Livingstone, 1983.

4) Kirschenbaum, M.A.: Severe mannitol-induced hyponatremia complicating transurethral prostatic resection. J. Urol., 121, 687-688, 1979.

5) Marberger, M.: Ultrasonic destruction of bladder sotones. Ultrasound in Urology. Baltimore, Williams and Wilkins, 1979.

6) Mulvaney, W.P.: The hydrodynamics of renal irrigations; with refehrence to calculus solvents. J. Urol., 89, 765-768, 1963.

7) Köhler, R.: Investigations in retrograde phelography; a roentgenological and clinical study. Acta Radiol,, Suppl., 99, p. 46, 1953.

(1985年 1 月 10 日受付) 